\title{
有明海湾奥部干潟前縁域の流動構造と懸濁態 物質輸送特性に関する現地観測
}

Spatial and temporal variations of current and suspended solid in the sub-tidal and inter-tidal zone at the Head of Ariake Sea

八木 宏1 1 井瀬 肇 2 ・松村航裕 $3 \cdot$ 不元克則4

Hiroshi YAGI, Hajime ISE, Kousuke MATSUMURA and Katsunori KIMOTO

1正会員 博 (工) 東京工業大学大学院助教授 情報理 工学研究科情報環境学専攻 ( $152-8553$ 東京都目黑区大岡山2-12-1)

2学生会員 東京工業大学大学院修士課程 情報理工学研究科情報環境学専攻

3学生会員 東京工業大学 工学部土木工学科

4非会員 (独法) 水産総合研究センター西海区水産研究所有明海・八代海漁場環境研究科長 ( T 851- 2213 長崎県長崎市多以良町1551- 8)

\begin{abstract}
Field observations were performed to understand the spatial and temporal variations of current and suspended solid in the sub-tidal and inter-tidal zone of Ariake Sea. The tidal currents are dominant in the sub-tidal and inter-tidal zone of Ariake Sea, while the wind has an important role on generating the residual currents. A large amount of sediment is suspended in the inter-tidal zone and the shallower region of sub-tidal zone due to the combined effect of tidal currents and wind waves. Large variations of Chlorophyll pigments concentration during the neap tide are induced in the sub-tidal zone due to the intrusion of Chlorophyll pigments from the offshore sub-surface layer.
\end{abstract}

Key Words : Ariake Sea, tidal current, wind-driven current, sub-tidal tidal zone, suspend solid

\section{1 .はじめに}

近年 , 有明海湾奥部では, 赤潮の頻発化やこれまで 好気的と考えられてきた干潟浅海域か㵅酸素化し，貝 類などの底生生物が大量整死するなど, 水環境の劣化 か著しいことか報告されている (例えば，木元ら $\left.{ }^{1)}\right)$ ． このように環境機能低下か著しい有明海，特に湾奥部 の水環境を保全・再生していくためには, 湾奥部に広 がる広大な泥質干潟域も含め, 浅海域から沖合海域ま でを一体として捉えた湾奥海域全体の物質循環構造や 生態環境機能を明らかにしていくことが不可欠である.

このうち湾奥沖合海域については, 湾スケールの流 れや水質構造 $\left(\right.$ 小松ら $\left.{ }^{2}\right)$, 懸濁物質の輸送特性 (中川ら $\left.{ }^{3)}\right)$, 懸濁物質の挙動と酸素消費速度 $\left(\right.$ 德永ら $\left.{ }^{4}\right)$ などに ついて現地観測をべースとした実態解明が行われてお り，一方，干潟域についても底泥輸送や底微小藻類な ど底質環境に関する検討 (田中 ${ }^{5)}$ ，八木ら ${ }^{6}$ ，山西ら ᄁ) か始まっているが, 沖合海域と干潟域間の物質輸送， 特に両者を結ふ汗潟前縁域の性質については, 弚の実 態を把握するための検討が行われておらず十分な理解 か得られているとは言えない．
そこで本研究では, 有明海湾奥部の佐賀県沖の干潟 域〜沖合海域を対象とし, 赤潮や貧酸素化か顕著な夏 季について, 流動構造や懸濁物質の輸送特性に関する 現地調査を行い，干潟前縁域の流れや成層構造，干潟 域〜沖合海域間の物質輸送特性を把握することを試み た。

\section{2 . 現地観測概要}

本研究では、夏季の干潟前縁域における流動構造と 懸濁物質の挙動を把握するために、有明海湾奥部の佐 賀県福富沖の干潟前縁域（図-1) において2005年8月7 日〜8月18日の期間に現地調査を行った . 調査内容は、 (1)干潟前縁域の岸沖方向 4 力所の固定観測点( Sta. 1- 4) における流速、水温、濁度、蛍光光度, 溶存酸素の連 続計測，(2)大潮時 (8/8)，小潮時( 8/15) における干潟前 縁域の流速, 塩分, 水温, 濁度, 蛍光光度, 溶存酸素 の岸沖断面構造計測( St a. A St a. 4) , (3) 1 潮汐間の懸 濁態物質の水平及び鉛直輸送フラックス計測 ( $8 / 10$, Sta.1-3) , (4) 貧酸素水塊の空間分布計測 (8/7, 8/13, 8/17) である . 観測期間は , 大潮終盤から小 


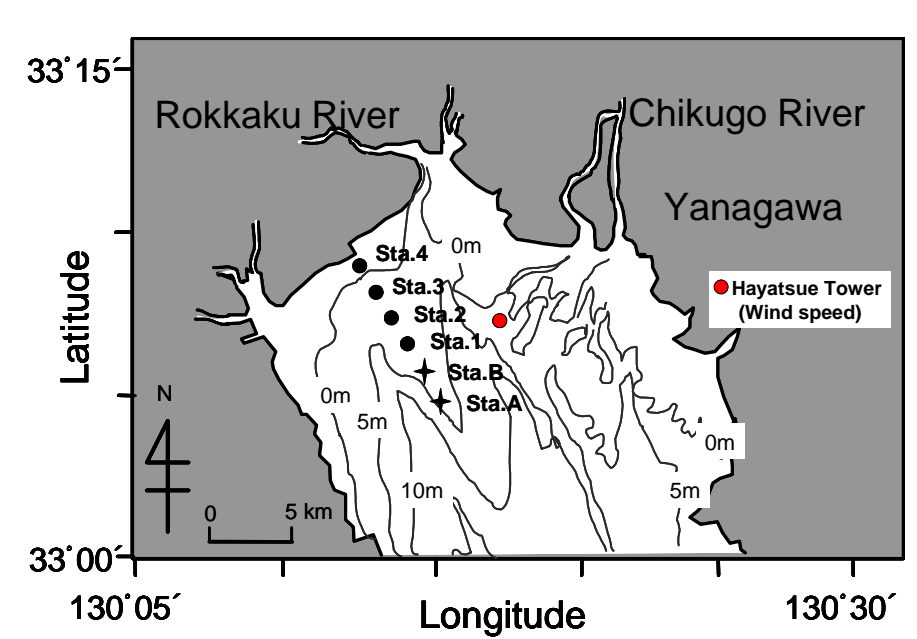

図-1 観測対象領域と観測点位置

潮を経て中潮の時期にあたり，また天候については夏 季の安定した晴天か続き, 出水など顕著な陸水影響は 見られなかった。なお, 本観測て計測された濁度, 蛍 光光度の計測值は, 田中ら ${ }^{5)}$ 力提案する換算式を用いて， SS , クロロフィル色素量 (クロロフィルa + フェオ色 素) に変換し以下の検討に用いている .

\section{3. 現地観測結果と考察}

\section{( 1)干潟前縁域の流動特性}

図-2( a) ( b) に , 観測期間中の潮位とSta. 2における底 層流速 (海底上0. $5 \mathrm{~m}$ ) の時系列を示す . 潮汐が大きい有 明海の特徵を反映し, 流速には半日周期の流速変動が 卓越している．図-3は，Sta.1〜4における観測期間全 体の底層流速をホドグラフとして表示したものである (但し，Sta.4は8/11-13のみ計測) . これを見ると，潮 流の主軸は, 湾軸方向よりも六角川河口方向の北側に ずれており，主軸の北側へのずれは陸岸に近づくほど 大きくなっている .このような潮流の特徵は, 陸岸と 六角川河口の存在による地形効果を反映したものと考 えられ, 高橋のの潮流数值シミュレーションの潮流楕円 の傾向と一致したものとなっている .

図-2(c) は，底面流速を25時間移動平均して算出した 平均流成分 (残差流) の時系列である. 残差流には顕 著な大潮小潮依存性は見られず，むしろ潮汐が大きい 観測期間前半に残差流が小さ，小潮期の8/13ごろか ら北東方向の残差流が発達している．図-4(a) には， St a. 2における流速鉛直分布の時間変化を示すが, 潮流 の主軸に近い南北方向の流速成分には，観測期間前半 を中心に明瞭な往復流力発生している，一方，東西方 向成分は，観測期間前半には，潮流に対応した往復成 分が見られるものの, 8/13以降に水深全体にわたって 東向きの流れか溌達しており，これが先に示した北東 方向の底層残差流に対応している。図-5に，観測期間

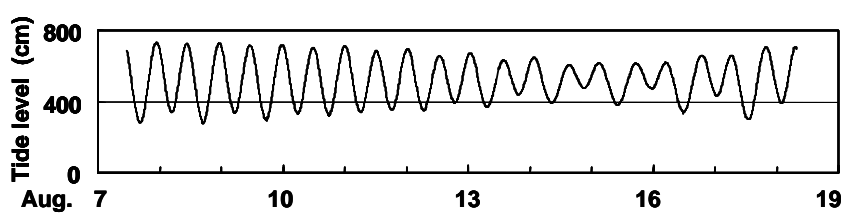

(a) 潮位

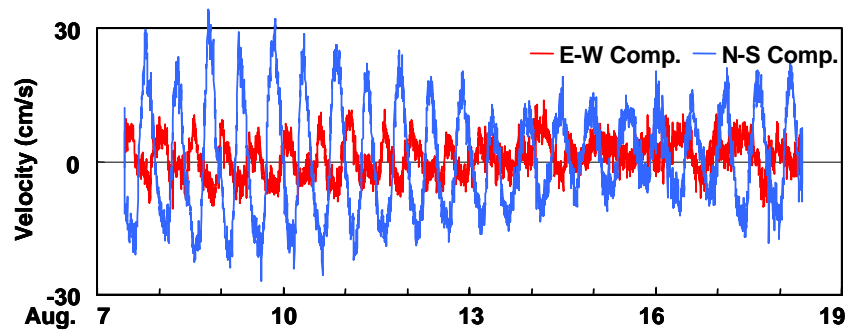

（b）底層流速

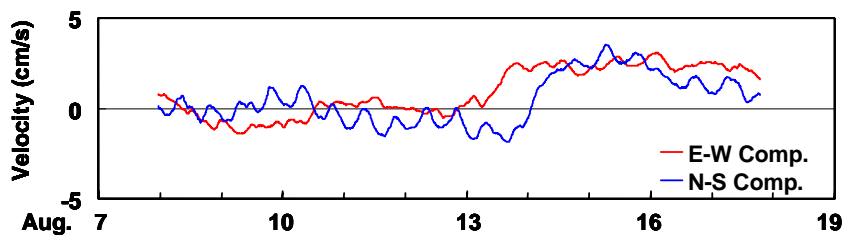

（c）底層流速の25時間平均 (残差流)

図-2 潮位とSta. 2における底層流速の時系列

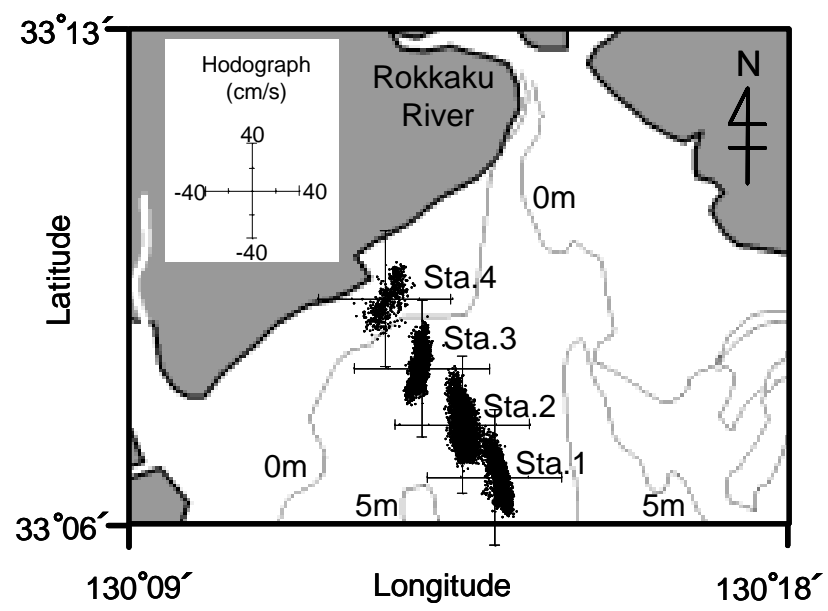

図-3 Sta.1〜4の底層流速のホドグラフ

中の海上風ベクトルの経時変化 (佐賀県水産振興セン ター早津江タワー, 図-1参照) を示すが，これを見る と，観測期間前半の8/8 8/12に比較的強い南風が連吹 しており，8/13以降西風に変化している．風向及び風 向変化の時期などから，観測期間後半に発達する北東 方向の残差流は海上風に起因したものと考えられ，潮 流が卓越する有明海湾奥部の干潟前縁域においても， 残差流には吹送流が重要な役割を果たしていることを 観測結果は示している。

図-4(b) には，図-4(a) に示した流速值から鉛直平均 流速を差し引いた流速偏差成分の時空間分布 (南北成 分）を示す . 潮流成分が大きい観測期間前半には，上 下の流速差が上げ潮 , 下げ潮ごとに変化しており，こ 
れは往復流である潮流の鉛直構造に起因したものであ る，一方，小潮期には，中層に潮位変化に連動して上 下する薄い北向き (岸向き) 流速の層か溌達している （図-4(c) 中の矢印の期間 A ）。この中層の薄い北向き流 速は，小潮期に顕著となる水温・塩分躍層付近に発生 することから，密度構造に起因することか推測される が, 弚の詳細な発生メカニズムについては今後さらに 検討する必要がある。

(2)干潟前縁域の懸濁態物質の時空変動構造と輸送特性 干潟前縁域の成層構造及ひ懸濁態物質の時間变動構 造と輸送特性について，(1)大潮期，小潮期に実施した 一潮汐間岸沖断面観測，(2)固定観測点における流速， 水温, 濁度 , クロロフィル色素量の連続計測結果に基 ついて，关の特徵を把握することを試みた 。

(a)王潟前縁域の岸沖断面構造

図一6に , 大潮期 , 小潮期における (a) 水温 , (b) SS , (c) クロロフィル色素量の岸沖断面分布と光の一潮汐間 の変化を示す . 水温の岸沖断面分布からわかるように , 大潮期，小潮期いずれの場合も，上げ潮時に沖合から 成層した水塊が潟前縁域に流入することで成層力漒 化され，下げ潮時に沖合に流出することで成層強度が 低下する傾向がある . 成層強度は大潮期と小潮期で異 なり, 小潮期には鉛直方向変化がシャープな水温, 塩 分躍層が形成され，干潮時の浅海域側においても躍層 か維持されるなど強い成層構造が発達している(塩分 躍層も水温躍層と同樣に発達) .このことは, 潮位差 が大きい有明海の浅海域であっても，小潮期には明確 な成層構造力発達することを示している．

懸濁態物質総量を表すSSについては, 満潮時の浅海 域底層で大きな值を示し，下げ朝から干潮にかけて高 濃度域が仲側に広がり，上げ潮時に岸側に移動してい る.小潮時には, 岸に近い浅海域底層でのみ濃度上昇 が見られ，干潟前縁域全体としては濃度レベルが低い． 以上の結果は, 基本的には大潮期の浅海域を中心とし て底質か大量に巻き上げられ, 弚れが潮流によって岸 沖方向に輸送されていることを示している．一方，ク ロロフィル色素量は, 小潮期の沖合海域亜表層から中 層に濃度レベルが高い領域 (クロロフィル極大層) が 存在することか特徵であり, 弚れが上げ潮時に干潟前 縁域に進入するなど, 沖合海域から干潟前縁域への影 響を考える上で重要な役割（植物プランクトンの流入 など）を果たしている．

(b) 懸濁態物質の時間変動特性

図-7に , St a. 1〜Sta. 4の底層(海底上50cm) のSSとク ロロフィル色素量の時系列を示す . SSの時間変動は， 基本的には潮汐に対応したものとなっており，いずれ の場所も干潮時前後の下げ潮後半, 上げ潮前半に濃度 レベルが高く , 小潮期よりも大潮期で濃度変動が大き い.また, 岸沖方向に比べると, 水深が浅い岸側の海
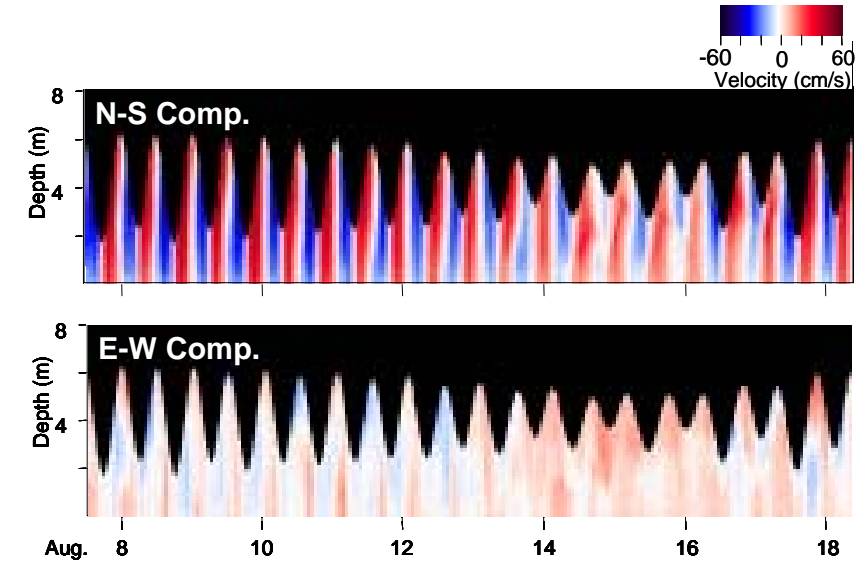

(a) 流速 (南北成分・東西成分)

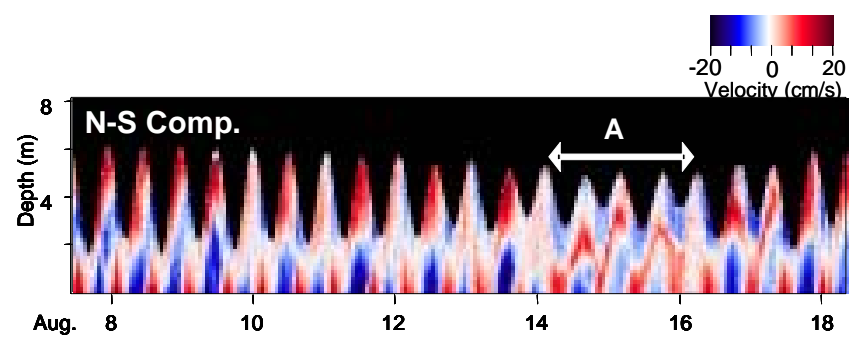

(b) 水深平均流速からの偏差成分 (南北成分)

図-4 St a. 2における流速の時空間コンター

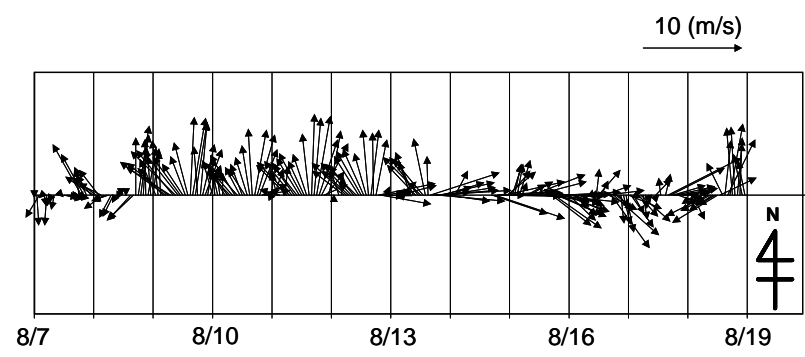

図-5 海上風ベクトルの時系列

域の方がS濃度レベルが高くなっており，これらの傾 向は, 先に示した大潮期 , 小潮期の岸沖断面計測結果 とも一致したものとなっている.このように, Ssの変 動は基本的には潮汐の影響を受けているが , 濃度変動 と潮差の関係を調べると，必ずしも潮差だけで濃度レ ベルが支配されているわけではない，本観測期間中で SS濃度変動が最も大きくなるのは8/9 (図中矢印B) で あり，潮差だけで考えれば，弚の前の $8 / 7,8$ 方が大き い. 図-5に示した , 海上風の経時変化からもわかるよ うに, SS濃度レベルが最大となる8/9以前は, 風速が比 較的小さく，8/9から強い南風が連吹している．南風が 連吹する8/9以降, 観測対象海域には海上風によって発 達したと思われる周期の短い風波か現地調査時に確認 されており，潮流に波浪の効果が重なることで, 水深 の浅い領域を中心に底質がより大きく巻き上げられ， 結果として大潮期のピークを過ぎた8/9に, SS濃度変動 


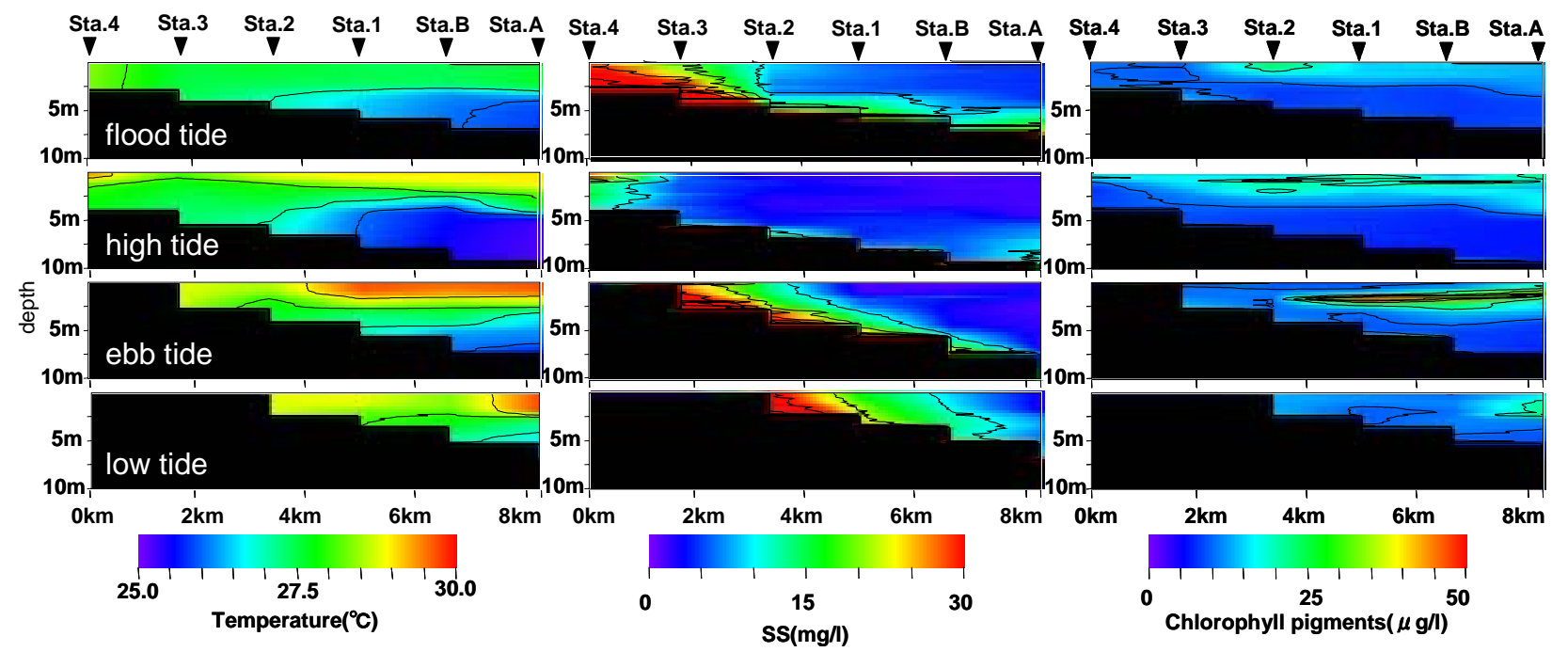

(a) 大潮期 ( 2005年8月9日)

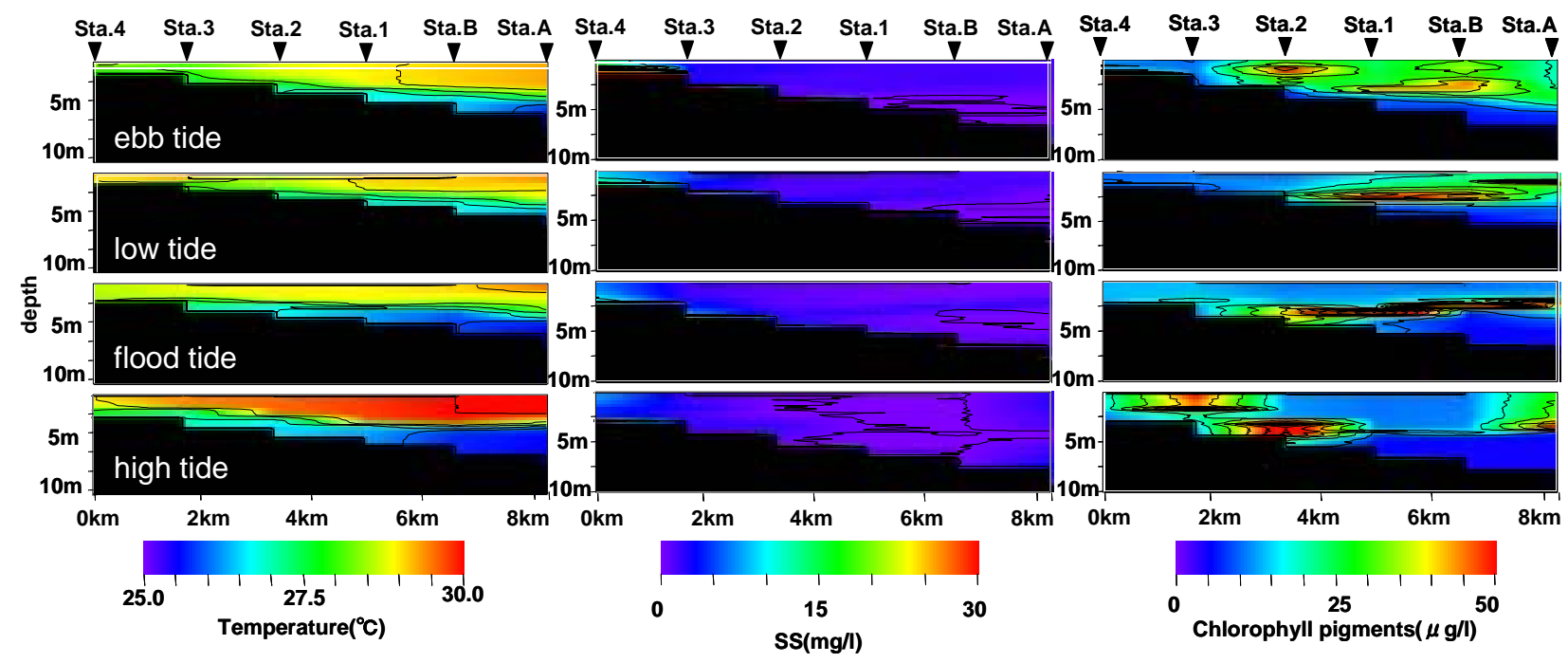

(b) 小潮期 (2005年8月15日)

図-6 水温, SS, クロロフィル色素量の岸沖断面分布

が最大となったものと推測される .

一方 , クロロフィル色素量は , 大潮期よりも小潮期 に濃度変動が大きい傾向がある. St a. 2における小潮期 の濃度ピーク (図中矢印C) は, 先に示した小潮期の岸 沖断面観測時に一致しているので沖合海域との関係を 調べると，小潮期に沖側海域の亜表層〜中層に形成さ れたクロロフィル極大層が上げ潮時に干潟前縁域にま て到達しており，これがSta. 2における底層クロロフィ ル色素量変動の原因あることがわかる (図-6参照) . このように，干潟前縁域では，小潮期を中心として沖 側海域のクロロフィル極大層から植物プランクトンが 供給され，底層の懸濁物質環境に影響を及ぼしている ことが考えられる .

\section{(C) 懸濁態物質の輸送特性}

図-8, 図-9に, Sta.2におけるSS及びクロロフィル色 素量フラックスの時系列を示す. 図中には，25時間移
動平均値も併せて表示している．これを見ると，濃度 变動に対応して , SSは大潮期〜中潮期に, クロロフィ ル色素量は小潮期に輸送フラックスが大きな值を示し ている.輸送方向は，25時間平均でみるといずれも岸 向きであり，沖合海域と干潟域をつなぐ干潟前縁域で は，SS及びクロロフィル色素 (植物プランクトン) と もに岸向きに輸送する性質があることがわかる．SSや クロロフィル色素量が岸向きに輸送されるメカニズム については, 数值シミュレーション等も併せて今後詳 細な検討をする必要がある .

4.おわりに

有明海湾奥部干潟前縁域における現地調査から，干 潟前縁域の流れや懸濁物質の時空間変動・輸送特性と 


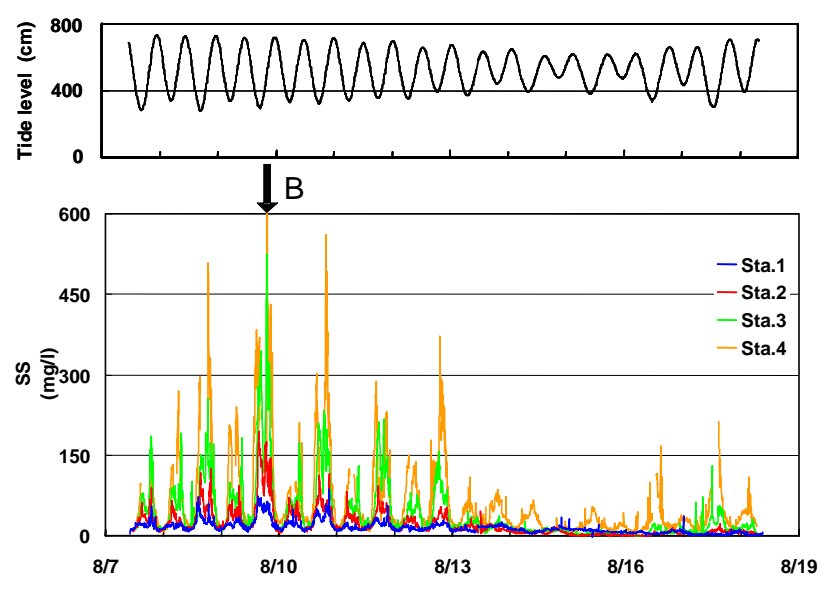

(a) SS

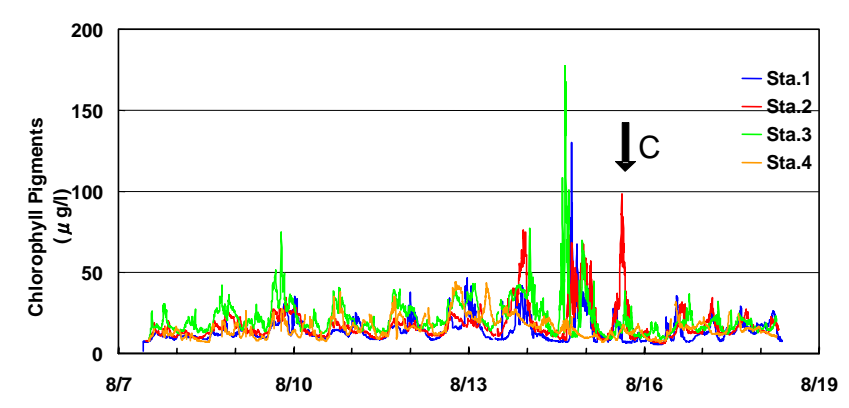

(b) クロロフィル色素量

图-8 SSとクロロフィル色素量の時系列

して以下の性質があることを示した .

1 . 有明海湾奥部干潟域〜沖合域の流れは, 基本的に は岸沖方向に往復する潮流が卓越しているが , 残差流 の形成には吹送流が重要な役割を果たしている．

2 . 懸濁態物質 (SS) は, 浅海域ほど濃度レベルが高 く，これは懸濁態物質の巻き上げに，潮流げけでな く，海上風によって生成された波浪の影響が大きい ことが原因と考えられる .

3.クロロフィル色素量の変動は, 大潮期よりも小潮 期に大きい．これは成層力顕著となる小潮期に沖合 海域亜表層〜中層に形成されるクロロフィル極大層 の干潟前縁域への流入の影響と考えられる .

4 . 懸濁態物質 (SS) フラックスは大潮期に , クロロ フィル色素量フラックスは小潮期に大きくなり，正 味の輸送方向（25時間平均）は，いずれも岸向きに なる .

謝辞 : 現地調査を行う上で、計測機器を提供して頂い た独立行政法人水産総合研究センター水産工学研究所 中山哲厳氏、西海区水産研究所 岡村和麿氏, 気象 データの提供並びに現地調査についてこ助言を頂いた 佐賀県有明水産振興センター川村嘉明氏、また現地調 査に多大な協力を頂いた西村商会(蛛)柴原芳一氏に対し てここに記して謝意を表します．また本研究は科学研

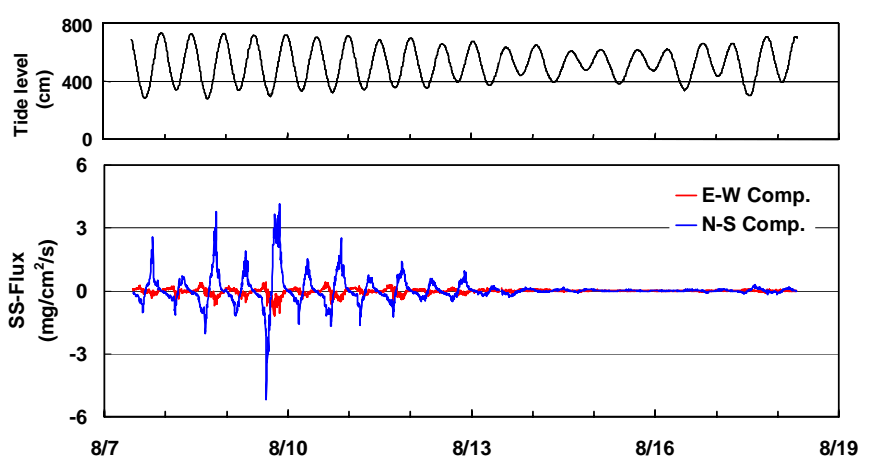

(a) SSフラックス

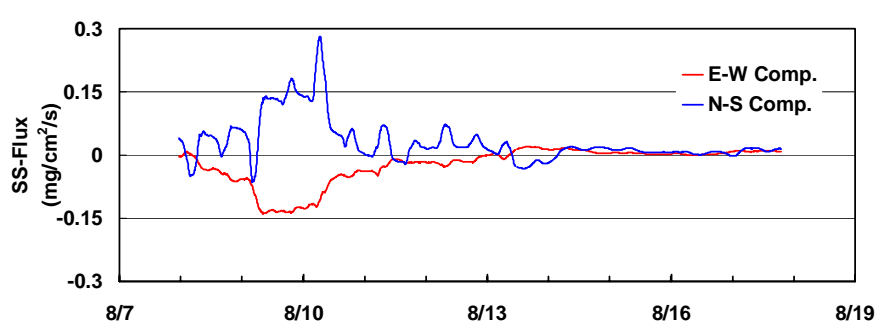

(b) SSフラックス (25時間平均)

图-9 Sta. 2におけるSSフラックスと潮位の時系列

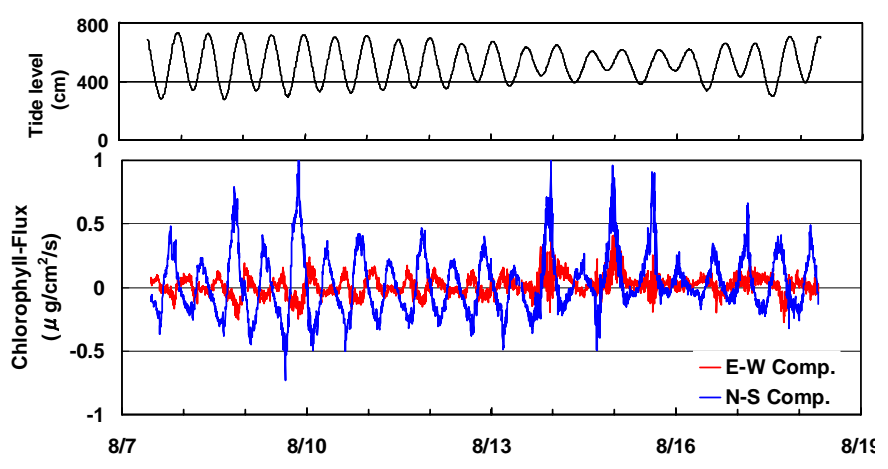

(a) クロロフィル色素量フラックス

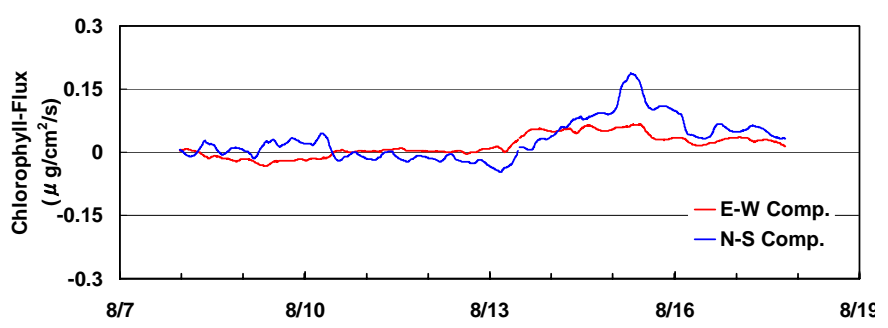

(b) クロロフィル色素量フラックス (25日诗間平均) 図-10 St a. 2におけるクロロフィル色素量フラックスと 潮位の時系列

究費基盤研究 (c) (課題番号 : 17560454, 代表者 : 八 木 宏) の補助を受けて行われたものである. 


\section{参考文献}

1) 木元克則 - 田中勝久 - 児玉真央 - 山本憲一 · 那須博 史 : 有明海奥部における貧酸素水塊の動態，2005年 度日本海洋学会春季大会講演要旨集, p196, 2005.

2) 小松利光 - 安達貴浩 - 金納聡 - 矢野真一郎 - 小橋乃 子・藤田和夫 : 有明海における流れと物質輸送に関 する現地観測，海岸工学論文集，第50巻，pp. 936940, 2003.

3) 中川博之 · 今林章二 · 末次広児 : 有明海の底泥輸送 現象に関する現地デー夕の解析, 海岸工学論文集, 第49巻, pp. 566- 570, 2002.

4) 德永貴久 ·松永信博 - 阿部淳 - 児玉真史 - 安田秀 一 : 有明海西部海域における高濁度層の観測と懸濁 物質による酸素消費の実験，土木学会論文集， No. 782, pp. 117- 129, 2005.

5) 田中勝久 - 児玉真史 - 熊谷香 - 藤本尚伸 : 有明海筑
後が差河口域における冬季のクロロフィル蛍光と濁 度変動, 海の研究 , 13巻, 2号, pp. 163 172, 2004.

6) 八木 宏·井瀬 肇・石田大暁・灘岡和夫 - 中山哲 嚴・小谷正幸 : 冬季有明海湾奥部浅海域における底 層懸濁態物質の空間構造と輸送特性, 海岸工学論文 集 , 第52巻, pp. 941- 945, 2005.

7) 山西博幸 - 荒木宏之 . 高哲煥 · 清川徹 - 茂木裕介 · 古賀憲一 : 有明海湾奥部干潟域における懸濁物輸送 と底泥付着藻類の変動特性に関する研究, 環境工学 研究論文集, Vol.40,pp. 587-594, 2003.

8) 高橋亜依 : 有明海湾奥部における流動構造と浮泥輸 送に関する研究, 東京工業大学大学院修士論 文, 100p. , 2003.

(2005. 9. 30受付) 